\title{
Developmental Study of Korean Lax, Tense and Aspirated Consonants in 2- to 7-Year-Old Children
}

\author{
Eun Joo Ryu ${ }^{a}$, Mi Jin Kim, Ji-Wan Ha ${ }^{\text {b,c }}$ \\ ${ }^{a}$ Department of Speech and Language Pathology, Graduate School of Rehabilitation, Daegu University, Gyeongsan, Korea \\ ${ }^{b}$ Department of Speech Pathology, Daegu University, Gyeongsan, Korea \\ 'International Institute of Rehabilitation Science, Daegu University, Gyeongsan, Korea
}

\author{
Correspondence: Ji-Wan $\mathrm{Ha}, \mathrm{PhD}$ \\ Department of Speech Pathology, Daegu \\ University, 201 Daegudae-ro, Jillyang-eup, \\ Gyeongsan 38453, Korea \\ Tel: +82-53-850-4327 \\ Fax: +82-53-850-4329 \\ E-mail: jw-ha@daegu.ac.kr
}

Received: June 30, 2019

Revised: August 5, 2019

Accepted: August 19, 2019

This research was supported by the Daegu University Research Grant, 2018.

\begin{abstract}
Objectives: In this study, we investigated the developmental patterns of lax, tense and aspirated sounds in words by age. We also compared the differences of the error patterns for three different phonation types among age groups, and identified age-appropriate error patterns. Methods: We conducted a word-level test of Urimal Test of Articulation and Phonology-2 (UTAP2) for typically developing children from 2 to 7 years of age in Seoul/Gyeonggi, Chungcheong, and Jeolla areas in Korea. We assessed children's speech accuracy in words with lax, tense and aspirated consonants. Also, we conducted a detailed review on characteristics of developmental error patterns shown by children. Results: Our study found that accuracy by phonation type was higher as the children's ages increased, and development of phonation types was almost completed at age 3 and stabilized at age 4 . The aspirated consonants were the slowest to develop, and their accuracy was lower than that of the other two phonation types until 3 years old. As a result of analyzing the error patterns reflecting the unique characteristics of Korean fricatives and regional dialects, this study consequently identified tensification of lax consonants and tensification of aspirated consonants as age-appropriate error patterns at age 2 . Conclusion: This study provides meaningful information on the development of error patterns and the accuracy of speech sound production by phonation types according to age, considering the characteristics of Korean in large-scale national data.
\end{abstract}

Keywords: Lax, Tense, Aspirated, Phonation types of Korean, Tensification of lax, Tensification of aspirated
영아들은 태어나면서부터 다양하고 반복적인 소리자극에 자연 스럽게 노출된다. 무질서한 소리자극 중에서 보호자가 들려주는 말소리에 더 큰 관심을 보이고 선택적으로 집중하게 됨에 따라, 점 차 의미 있는 의사소통이 가능해진다. 이러한 말소리의 지각 능력 은 영아기 동안 매우 민감하게 발달한다(Eimas, Siqueland, Jusczyk, \& Vigorito, 1971). 모국어에 없는 음소에 대해서도 영아기에는 변별이 가능하다가 이후 연령이 증가함에 따라 모국어 음소체계에 국한된 말소리만을 변별을 하게 된다(Burnham, Earnshaw, \& Clark, 1991). 매우 이른 시기부터 시작된 말소리의 음소 차원의 지 각은 연령이 증가함에 따라 음소 자체보다 음소의 대립에 더욱 초 점을 두게 된다. 이러한 과정을 발판으로 그 나라 언어체계 내의 음
소들에 대한 상호변별능력이 갖추어지면, 영아들은 자발적으로 체 득한 구강구조의 움직임을 통해 말소리들을 구분하여 산출할 수 있게 된다. 초기 말소리산출과 관련하여 국내외에서 실시한 연구 를 살펴보면, 먼저 Stoel-Gammon (1985)은 영어권의 경우 초성에 서 파열음, 비음, 활음, 마찰음, 파찰음, 유음 순서로 자음이 발달되 며, 무성음보다 유성음이 더 먼저 산출된다고 보고하였다. 국내에 서는 Moon과 $\mathrm{Ha}$ (2012)가 1-2세 일반유아의 말소리목록을 연구하 였는데, 그 결과 조음위치별로는 양순음이, 조음방법별로는 파열 음과 비음이, 발성유형별로는 경음이 가장 많이 나타난다고 보고 하였다.

이 가운데 발성유형의 차이는 한국어의 독특한 특성으로, 이로 
인해 한국어 자음의 분류체계는 다른 언어와 상이하게 구별된다. 유무성의 대립으로만 나뉘어지는 영어와는 달리, 한국어의 경우 성대의 진동 여부보다 성도의 영역이 음소변별에 기여하는 바가 크 다. 한국어는 변별자질 측면에서 기식성과 긴장성의 유무라는 발성 유형적 차이에 따라, [-긴장성], [-기식성]의 평음, [+긴장성], [-기식 성]의 경음 [+긴장성], [+기식성]의 격음으로 구분된다. 음성학적 측 면에서 평음은 기식성을 가지고는 있으나 격음의 기식성보다는 약 하고 성대를 긴장시키지 않은 상태에서 발음하는 소리, 경음은 공 기를 거의 방출하지 않고 성대를 긴장시켜 발음하는 소리, 격음은 기식성이 강하고 성대를 긴장시켜 발음하는 소리로 설명할 수 있 다. 한국어 장애음 가운데 파열음과 파찰음은 음운적으로 평음, 경 음, 격음 삼중대립을 이루는 반면, 마찰음은 격음이 빠진 평음과 경 음 이중대립을 이룬다(Kim, Cho, Hwang, \& Nam, 2002).

산출 측면에서 발성유형의 발달 양상은 언어에 따라 다소상이하 다. 영어가 모국어인 아동은 2세 6 개월에 이미 성인과 유사한 수준 의 유무성 대립을 습득하는 반면, 한국어가 모국어인 아동은 4 세 경까지도 세 발성유형 간 상당한 음향학적 중첩현상이 확인되었다 (Kim \& Stoel-Gammon, 2009). 또한 Ahn과 Kim (2003)은 유아들 에서 평음, 경음, 격음 간 대치현상을 보고하였는데, 24개월 이전 유 아의 경우 평음과 경음, 경음과 격음, 평음과 격음 등이 서로 대치되 는 현상이 매우 흔하게 나타난다는 것이다. 이후 24 개월에서 30 개 월 사이 이러한 양방향적 대치가 줄어들고 평음과 격음이 경음으 로 대치되는 비율이 눈에 띄게 높아진다고 한다. 이처럼 한국어 파 열음의 발달과정에서 경음에 비해 음도가 낮은 평음이 더 늦게 발 달하는 것은 한국어 고유의 발달적 패턴으로 보고된 바 있다(Kim \& Stoel-Gammon, 2011).

발성유형에 대한 한국어의 독특한 분류체계는 마찰음에서도 찾 아볼 수 있다. 앞서 언급한 대로 마찰음은 파열음과 파찰음과는 달 리, 평음과 경음으로 이중대립을 이루며 예외적인 특징을 나타낸 다. 그러나 현재까지도 마찰음 / 시와 / 씨 음가에 대해 평음, 경음, 격음 중 과연 어디에 분류를 하는 것이 가장 적합한가를 두고 음운 론적 및 음성학적 차원에서 서로 다른 의견들이 대립하고 있다. 그 이유는 치경마찰음 / 시와 / 씨의 경우 앞에서 설명하였던 장애음 의 평음, 경음과는 달리, 격음에 가까운 기식성이 포함되어 있기 때 문이다. 이에 대해 Kim (1997)은 음운론과 음성학적 견해를 모두 반영한 결론을 제시하기도 하였는데, 즉, / ㅅ/는 평음과 격음의 역 할을, /씨는 평음과 경음의 역할을 한다는 것이다. 그뿐만 아니라 마찰음의 이 같은 이중적인 성질을 반영하여, 말소리 오류분석 시 에는 어두 위치에서 마찰음/ㅅ/,/씨를/E/나/ㅊ/로 대치하더라도 격음화로 분석하지 않는다(Kim, 2006; Kim, Kim, \& Stoel-Gam- mon, 2017). 또한, 한국어 마찰음 특성에 대해 살펴본 Ruy와 $\mathrm{Ha}$ (2019)의 연구에 따르면, 어두 위치에서 마찰음/ㅅ/와 / ㅆ/에 대한 격음 대치는 물론, 어중 위치 특히 장애음과 연속된 어중 위치에서 도 / 씨는 해당 음소가 가지고 있는 강한 기식성의 성질로 인해 격 음으로 대치가 빈번하며, 따라서 단어 내 위치와 관계없이 마찰음 이 다른 격음의 음소로 대치되는 현상에 대해 발성유형의 오류로 분석하는 것은 맞지 않다고 주장한 바 있다. 이처럼 마찰음/시와/ 씨는 음가 내 포함되어 있는 기식성으로 인해 다른 평음, 경음과는 상이하게 구분되는 특성을 지니고 있다.

그뿐만 아니라 긴장성과 기식성의 유무로 구분되는 한국어 발성 유형의 특성은 지역적 방언에 따라서도 다양한 대치오류를 유발한 다. 지역적 방언과 관련하여 그 특성이 특히 뚜렷한 곳은 경상도이 다. 방언에 대한 Choi (1982)의 조사에 따르면, 영남의 일부 지역에 서는 평음/바, ᄃ, ᄀᄀ, 지가 어두에서 실현될 경우 평음 대신 경음 으로 발음된다. 또한 경북의 동남지역(청도, 경산, 칠곡, 성주, 영천, 청도 등)에서는 / 시와 / 씨가 변별되지 않아, /쌀/을 [살]로 발음하 는 평음화 오류를 나타내기도 한다. 반면 경북의 북서부 지역(상주, 문경, 예천, 안동, 영주 등)은/시와/씨의 변별에 어려움이 없는 것 으로 보고되었다. 이와 관련하여 $\mathrm{Ryu}$ 와 $\mathrm{Ha}$ (2019)는 서울, 경기, 충 청 경상, 전라 등의 지역에 거주하는 2-7세 일반아동 총 537명을 대 상으로 지역적 방언 특성에 따른 마찰음 대치 오류를 살펴보았다. 그 결과, 서울/경기 $0 \%$, 충청 $7 \%$, 전라 $0 \%$, 경상 $18 \%$ 로 경상도 지역 에서 경 마찰음/씨에 대해 평 마찰음/시로 대치하는 오류가 가장 많이 나타난 것으로 확인되었다. 이러한 결과를 토대로 살펴볼 때, 경상도 지역의 방언적 특성이 다른 지역에 비해 강하다는 것을 다 시 한 번 확인할 수 있었다. 그뿐만 아니라 실험에 참가한 대상자의 연령이 2-7세인 것을 감안할 때 이와 같이 강한 방언적 특성은 아 동들의 말소리 발달과정에서도 충분히 그 영향을 미칠 수 있음을 시사한다. 따라서, 지역에 따라 말소리 발달과 관련하여 전국 규모 의 연구를 진행할 경우, 지역적 방언의 특성은 중요하게 고려해야 할 요소 중 하나라고 할 수 있다. 인접한 지역 내에서도 일관되지 않 은 방언적 특성이 나타나는 현상과 관련하여, 앞에서 설명하였던, 우리말 평음과 격음 간, 평음과 경음 간 기식성과 긴장성에 대한 음 성학적 연장선, 그로 인한 음소적 경계의 모호성에서 그 이유를 찾 아볼수 있을 듯하다.

이처럼 우리말에서 발성유형 간 음성학적 차이가 두드러지지 않 음으로써 음소적 대립에 어느 정도 혼란을 겪을 수밖에 없다면, 아 동의 말소리에서도 세 발성유형을 변별하고 습득하여 안정되게 산 출하기까지는 결코 쉬운 여정이 아닐 것이다. 아동기에 나타나는 발 성유형 오류와 관련하여 경음화 오류가 후기 말소리 발달 시기인 
4세까지 출현하는 것으로 보고된 바 있다(Kim et al., 2017). 말소리 발달의 안정기라 할 수 있는 4 세에서도 여전히 경음화 오류가 나타 난다는 것은 발성유형 간 상대적인 음성학적 차이를 음소적 경계 로 명확하게 구분하여 산출하는 것이 일반아동들에게도 부담스러 운 일임을 시사한다. 그뿐만 아니라 경음화라는 발달적 오류는 다 른 언어권의 아동들은 보이지 않는, 즉 언어보편적이지 않은 음운 오류패턴으로, 이는 다른 언어체계와는 다른 우리말의 특성을 반 영하는 것이다. 따라서 말소리 발달과정 중 나타나는 발성유형 오 류에 대해 우리말 발성유형의 독특한 특성과 관련하여 알아볼 필 요가 있다.

이에 본 연구에서는 2 세 후반부터 7세 일반아동들을 대상으로, 한국어의 말소리 및 방언적 특성을 반영한 한국어 평음, 경음, 격음 의 발달과정을 알아보고자 하였다. 이를 위해 현재 개발 중인 $\mathrm{UTAP} 2$ 단어수준 검사의 항목 중 평음, 경음, 격음이 포함된 단어 들에 대한 대상자들의 정반응 및 오반응을 분석하여, 연령에 따른 발성유형별 정확도와 발달적 오류패턴의 특성을 살펴보았다.

\section{연구방법}

\section{연구대상}

본 연구의 대상은 서울/경기, 충청, 전라 등의 지역에 거주하는 2 세 50명, 3세 80명, 4세 98명, 5세 89명, 6세 49명, 7세 32명으로 총 398 명의 일반아동들이었다. 대상아동의 선정조건은 첫째, 서울, 경 기, 충청, 전라 등의 지역에 거주하고 생활연령이 2세 6개월부터 7세 11 개월 사이에 해당하는 아동, 둘째, 수용·표현어휘력검사(Receptive \& Expressive Vocabulary Test, REVT; Kim, Hong, Kim, Jang, \& Lee, 2009) 결과 수용어휘 능력이 -2 SD 이상인 아동, 셋째, 우리 말 조음음운평가(Urimal Test of Articulation and Phonology, UTAP; Kim \& Shin, 2004) 결과 단어수준의 자음정확도가 -2 SD
이상인 아동이었다. 경상지역 아동의 경우, 다른 지역에 비해 상대 적으로 방언 특성이 아동의 말소리 발달에도 영향을 미칠 수 있다 는 선행연구(Ryu \& Ha, 2019) 결과에 근거하여, 본 연구에는 포함 시키지 않았다. 연구에 참여한 대상아동의 지역, 연령 및 성별 분포 는 Figure 1과 Table 1에 각각 제시하였다.

\section{검사도구 및 실험방법}

본 연구에서는 2세 후반에서 7세 아동의 조음음운능력을 평가 하기 위해 현재 개발 중인 UTAP2 (Kim et al., 2018)의 단어수준 검 사의 항목들을 이용하였다(Appendix 1). 실험은 소음의 영향을 최 소화한 분리된 공간에서 검사자와 아동이 일대일로 진행되었다. 총 30 개의 그림을 하나씩 보여주면 자발적으로 이름을 말하는 대면이 름대기 방식이 기본적인 실험절차였지만, 아동이 자발적으로 그림 이름을 말하지 못할 경우 의미단서를 제시하였고, 의미단서 제시 후에도 대답을 못할 경우 따라말하기를 통해 반응을 유도하였다. 검사자는 현장에서 아동의 반응을 기록지에 바로 전사하였고, 실 험 후 녹음 또는 녹화된 발화를 재생하여 전사결과를 다시 한 번 점검 및 보완하는 과정을 거쳤다.

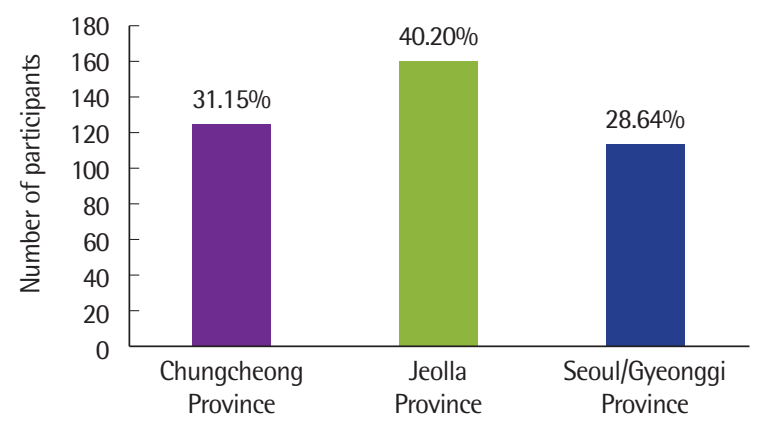

Figure 1. Number of participants by region.

Table 1. The characteristics of participants

\begin{tabular}{|c|c|c|c|c|c|c|}
\hline & \multicolumn{6}{|c|}{ Typically developing children } \\
\hline & 2 years & 3 years & 4 years & 5 years & 6 years & 7 years \\
\hline Number of participants & 50 & 80 & 98 & 89 & 49 & 32 \\
\hline \multicolumn{7}{|l|}{ Gender } \\
\hline Male & 23 & 35 & 53 & 37 & 21 & 16 \\
\hline Female & 27 & 45 & 45 & 52 & 28 & 16 \\
\hline Chronological age (mo) & $32.64(1.36)$ & 40.82 (3.58) & $53.03(3.04)$ & $66.08(3.28)$ & $75.48(2.71)$ & $87.96(3.11)$ \\
\hline REVT-Receptive vocabulary score & $20.96(9.87)$ & $29.60(11.72)$ & $46.08(12.90)$ & $61.90(11.02)$ & $72.00(11.42)$ & $86.91(13.70)$ \\
\hline PCC at UTAP (\%) & $76.40(13.50)$ & $82.84(12.15)$ & $90.88(8.14)$ & $98.15(3.55)$ & $98.86(2.21)$ & $99.45(1.10)$ \\
\hline
\end{tabular}

Values are presented as mean (SD).

REVT= Receptive \& Expressive Vocabulary Test (Kim, Hong, Kim, Jang, \& Lee, 2009); UTAP=Urimal Test of Articulation and Phonology (Kim \& Shin, 2004); PCC= percentage of consonants correct. 


\section{자료 처리 및 통계 분석}

UTAP2의 전체 30 개 단어항목 가운데 단어 내 자음을 평음, 경 음 또는 격음으로 구분할 수 없는 항목, 즉 유음, 비음, 그리고 성문 마찰음 /하만으로 구성된 단어(나무, 호랑이, 라면)는 본 연구의 분석에서 제외하였다. 분석에 포함된 총 27 개 단어에 대해 평음, 경 음, 격음의 기회수를 산출한 결과, 평음이 23 회, 경음이 14 회, 격음 이 11 회였다. 발성유형의 정확도는 각 발성유형의 기회수에서 올바 르게 조음한 정조음수의 비율을 백분율로 산출하여 구하였다. 예 를 들어 평음에 대해 정확하게 조음한 음소가 20 개라면, 평음의 정 확도는 86.95 점 $(=20 / 23 \times 100)$ 이 된다.

음운오류패턴의 경우 평음에서는 평음의 경음화와 평음의 격음 화가, 경음에서는 경음의 평음화와 경음의 격음화가, 격음에서는 격음의 평음화와 격음의 경음화가 나타날 수 있다. 오류 점수는 이 러한 음운오류패턴에 근거하여, 각 발성유형의 기회수에서 해당 음 운오류패턴의 출현횟수의 비율을 백분율로 산출하여 구하였다. 예 를 들어 27 개의 단어 중 / 접씨/와/사탕/에 대해 [떱띠], [따탕]이라 고 발음을 했다면, 평음의 경음화 오류는 2 회로 계산된다. 평음의 경음화를 2 회 보인 경우, 평음의 총 기회수인 23 을 분모로, 오류수 인 2 를 분자로 하여 100 을 곱하면 오류 점수는 8.70 점이 된다. 이때 선행연구(Kim, 2006; Kim et al., 2017)를 참고하여 마찰음/시의 경우 격음에 가까울 정도의 비교적 강한 기식성을 가지고 있기 때 문에, 평음/시를 [E], [치와 같은 격음으로 대치를 하더라도 평음 의 격음화에 포함시키지 않았다(예: / 사탕/을 [타탕] 또는 [차탕]으 로 발음한 경우). 또한, 경 마찰음 / 씨 역시 선행연구(Ryu \& $\mathrm{Ha}$, 2019)를 통해 어두 초성 위치와 장애음과 연속된 어중 초성 위치에 서 격음으로의 대치가 빈번하다는 것을 알 수 있었다. 따라서 마찰 음 /씨가 오조음될 경우 기식성이 첨가되더라도 경음의 격음화에 포함시키지 않았다(예: /접씨/, /책쌍/을 [접치], [책창]으로 발음한 경우). 본 연구에서는 발성유형 이외에 조음방법, 조음위치와 관련 한 다른 오류들은 분석하지 않았다.

또한 각 연령집단에서 해당 음운오류패턴을 보인 아동 비율에 근거하여, 발생유형 오류에 대해 '나이에 적절한 음운오류패턴'을 파악하고자 하였다. Dodd, Holm, Hua와 Crosbie (2003)는 발달적 오류패턴과 비발달적 오류패턴에 대한 구체적인 기준을 제안한 바 있다. 발달적 및 비발달적 오류패턴을 결정하기 위해서는 그 보다 우선 일반아동의 정상적인 발달과정 중 나타날 수 있는 나이에 적 절한 오류패턴에 대한 기준이 마련되어야 하는데, 이에 대해 Dodd 등(2003)은 해당 연령대 아동의 $10 \%$ 이상이 사용하는 오류패턴을 나이에 적절한 것으로 규정하였다. 따라서 본 연구에서도 Dodd 등 (2003)의 기준을 적용하여 각 연령집단에서 대상자의 $10 \%$ 이상이
사용한 오류패턴을 나이에 적절한 것으로 간주하였다. 특정 음운 오류패턴의 출현 비율을 살펴보기 위해 각 연령집단에서 특정 음 운오류패턴을 2 회 이상 보인 대상자의 비율을 백분율로 계산하여 산출하였다. 예를 들어, 2 세 전체 아동 63 명 중 10 명이 평음의 경음 화 오류를 2 회 이상 보인 경우, 2 세 전체 아동수 63 을 분모로, 오류 를 보인 아동수 10 을 분자로 하여 100 을 곱하면 $15.87 \%$ 가 된다. 이 러한 결과값을 기준으로 출현 비율이 $10 \%$ 이상일 경우 나이에 적 절한 오류패턴으로 구분하였다.

통계분석은 SPSS version 20.0 for Window 프로그램을 이용하 여 다음과 같이 실시하였다. 첫째, 연령별 발성유형(평음, 경음, 격 음)에 따른 정확도의 차이를 알아보기 위해 1 피험자 간-1피험자 내 혼합설계에 따른 반복측정 분산분석을 실시하였다. 둘째, 평음, 경 음, 격음 각각에서 연령별 음운오류패턴의 종류(평음은 경음화와 격음화, 경음은 평음화와 격음화, 격음은 평음화와 경음화)에 따른 차이를 알아보기 위해 1피험자 간-1피험자 내 혼합설계에 따른 반 복측정 분산분석을 실시하였다. 연령 간 차이에 대한 사후분석은 Scheffe 사후검정을, 발성유형별 차이에 대한 사후분석은 Bonferroni 검정을, 상호작용효과에 대한 사후분석은 COMPARE syntax 를 입력하여 실시하였다. 모든 통계학적 유의수준은 .05에 맞추어 분석하였다.

\section{신뢰도}

발성유형별 정확도와 음운오류패턴에 대한 신뢰도를 검증하기 위해 평가자 간 신뢰도를 실시하였다. 제 1 평가자는 제 1 저자로 임상 경력 7년 이상의 1 급 언어재활사 자격증을 소지하였고, 제 2 평가자 는 제 2 저자로 임상경력 11 년 이상의 2 급 언어재활사 자격증을 소지 하였다. 약 6 개월간의 연습과 논의를 통하여 5 명에 대한 두 평가자 간 일치도가 $95 \%$ 이상인 것을 확인한 후, 전체 대상자의 $20 \%$ 에 해 당하는 80 명의 자료를 무작위로 추출하여 신뢰도 평가를 실시하였 다. 신뢰도는 제 1,2 평가자 간 일치하는 항목과 불일치한 항목수의 합을 일치한 항목수로 나눈 후 100 을 곱하여 산출하였다. 발성유형 별 정확도 및 음운오류패턴에 대한 일치도는 $88.75 \%$ 이었다.

\section{연구결과}

\section{연령에 따른 발성유형별 정확도 차이}

연령에 따른 발성유형별 정확도에 대한 기술통계 결과는 Table 2 에 제시하였다. 평균적으로 연령이 높아질수록 발성유형별 정확도 가 향상되었음을 알 수 있다. 이와 같은 차이가 통계적으로 유의한 지 알아본 결과, 집단 간 주효과가 유의하였고 $\left(F_{(5,392)}=5.722, p<\right.$ 
$.05)$, 발성유형별 주효과 $\left(F_{(2,784)}=5.508, p<.05\right)$, 집단과 발성유형의 상호작용효과 $\left(F_{(10,784)}=1.892, p<.05\right)$ 가 모두 유의하였다. 연령별 차이에 대한 사후검정 결과, 2 세는 4 세 이후 모든 집단보다 정확도 가 유의하게 낮았던 반면( $p<.05), 3$ 세 집단부터는 연령 간 유의한 차이가 관찰되지 않았다. 발성유형별 차이에 대한 사후검정 결과, 평음이 격음보다 유의하게 점수가 높은 것으로 나타난 반면 $(p<$ .05), 평음과 경음 간, 경음과 격음 간 차이는 유의하지 않았다. 연령 과 발성유형의 상호작용효과에 대한 사후검정 결과, 2세와 3세 집 단에서는 격음의 정확도가 평음과 경음 $(p<.05)$ 보다 유의하게 떨 어진 반면, 4 세 이후부터는 발성유형에 따른 정확도에 유의한 차이 가 관찰되지 않았다.

\section{연령별 발성유형의 오류 비교분석}

\section{평음의 오류패턴 비교}

연령에 따른 평음 음운오류패턴(평음의 경음화, 평음의 격음화) 에 대한 기술통계 결과는 Table 3과 같다. 평음의 음운오류패턴별 차이가 통계적으로 유의한지 살펴본 결과, 집단 간 주효과가 $\left(F_{(5,392)}=7.719, p<.05\right)$, 오류패턴 종류에 따른 주효과 $\left(F_{(1,392)}=\right.$

Table 2. Descriptive analysis on accuracy by phonation type according to age groups

\begin{tabular}{lccl}
\hline \multirow{2}{*}{ Age group } & \multicolumn{3}{c}{ Accuracy $(\%)$} \\
\cline { 2 - 4 } & \multicolumn{1}{c}{ Lax } & Tense & Aspiration \\
\hline 2 years & $96.96(5.33)$ & $95.46(9.62)$ & $94.80(14.39)$ \\
3 years & $98.70(3.73)$ & $95.36(8.03)$ & $97.21(9.79)$ \\
4 years & $99.62(1.22)$ & $97.98(4.64)$ & $99.27(3.30)$ \\
5 years & $99.84(1.00)$ & $99.48(1.86)$ & $99.33(2.94)$ \\
6 years & $99.93(0.05)$ & $99.68(1.47)$ & $99.46(2.15)$ \\
7 years & $100(0.00)$ & $99.69(1.45)$ & $99.80(1.32)$ \\
Total & $99.23(2.76)$ & $97.81(5.82)$ & $98.40(7.17)$ \\
\hline
\end{tabular}

Values are presented as mean (SD).
$9.642, p<.05)$, 집단과 오류패턴 종류의 상호작용효과 $\left(F_{(5,392)}=\right.$ $3.010, p<.05)$ 가 모두 유의하였다. 집단 간 주효과에 대한 사후검정 결과, 2 세는 4 세 이후 모든 집단보다 오류를 유의하게 많이 보였고 $(p<.05), 3$ 세 이후 연령집단 간에는 유의한 차이가 관찰되지 않았 다. 오류패턴 종류에 대한 사후검정 결과, 평음의 경음화가 평음의 격음화보다 유의하게 많이 출현하였다 $(p<.05)$. 마지막으로 집단과 오류유형의 상호작용효과에 대한 사후검정 결과, 2 세와 3 세의 경 우 평음의 경음화가 평음의 격음화보다 유의하게 높게 나타난 반면 ( $p<.05), 4$ 세 이후부터는 모든 연령에서 오류패턴 간 유의미한 차 이가 없었다.

\section{경음의 오류패턴 비교}

연령에 따른 경음 음운오류패턴(경음의 평음화, 경음의 격음화) 에 대한 기술통계 결과는 Table 3에 제시하였고, 경음의 음운오류 패턴별 차이가 통계적으로 유의한지 알아보았다. 그 결과, 집단 간 주효과가 유의하지 않았다. 오류패턴 종류에 따른 주효과는 유의 한 $\left(F_{(1,392)}=11.238, p<.05\right)$ 반면, 집단과 오류패턴 종류의 상호작용 효과는 유의하지 않았다. 오류패턴 종류에 대한 사후검정 결과, 경 음의 평음화는 경음의 격음화보다 유의하게 많이 출현하였다 $(p<$ .05).

\section{격음의 오류패턴 비교}

연령에 따른 격음의 음운오류패턴(격음의 평음화, 격음의 경음 화)에 대한 기술통계 결과는 Table 3 에 제시하였고, 격음의 음운오 류패턴별 통계적인 차이를 살펴본 결과, 집단 간 주효과 $\left(F_{(5,392)}=\right.$ $3.799, p<.05)$, 오류패턴 종류에 따른 주효과 $\left(F_{(1,392)}=12.506, p<\right.$ .05)가 유의한 반면, 집단과 오류패턴 종류의 상호작용효과는 유의 하지 않았다. 집단 간 차이에 대한 사후검정 결과, 2 세와 3 세 집단 은 나머지 모든 연령 집단과 유의미한 차이가 있었다( $p<.05)$. 오류

Table 3. Descriptive analysis on phonation type error patterns according to age groups

\begin{tabular}{|c|c|c|c|c|c|c|}
\hline \multirow{3}{*}{ Age group } & \multicolumn{6}{|c|}{ Phonological error patterns (\%) } \\
\hline & \multicolumn{2}{|c|}{ Lax } & \multicolumn{2}{|c|}{ Tense } & \multicolumn{2}{|c|}{ Aspirated } \\
\hline & Tensification & Aspiration & Unfortified & Aspiration & Unfortified & Tensification \\
\hline 2 years & $1.92(4.14)$ & $0.52(2.08)$ & $1.85(7.47)$ & $0.42(2.24)$ & $1.63(9.12)$ & $3.63(8.41)$ \\
\hline 3 years & $1.19(4.14)$ & $0.21(0.95)$ & $0.80(2.27)$ & $0.17(1.12)$ & $0.34(1.73)$ & $3.18(10.9)$ \\
\hline 4 years & $0.17(0.86)$ & $0.13(0.75)$ & $1.23(3.97)$ & $0.07(0.72)$ & $0.00(0.00)$ & $0.92(3.80)$ \\
\hline 5 years & $0.14(1.02)$ & $0.00(0.00)$ & $0.40(1.65)$ & $0.08(0.75)$ & $0.00(0.00)$ & $0.71(3.13)$ \\
\hline 6 years & $0.08(0.62)$ & $0.00(0.00)$ & $0.29(1.42)$ & $0.00(0.00)$ & $0.00(0.00)$ & $0.55(2.20)$ \\
\hline 7 years & $0.00(0.00)$ & $0.00(0.00)$ & $0.22(1.26)$ & $0.00(0.00)$ & $0.00(0.00)$ & $0.00(0.00)$ \\
\hline Total & $0.56(2.53)$ & $0.14(0.94)$ & $0.84(3.61)$ & $0.12(1.06)$ & $0.27(3.34)$ & $1.55(6.36)$ \\
\hline
\end{tabular}

Values are presented as mean (SD). 
Table 4. Frequency of phonological error patterns of the phonation types by age groups

\begin{tabular}{|c|c|c|c|c|c|c|}
\hline \multirow{3}{*}{ Age group } & \multicolumn{6}{|c|}{ Frequency of phonological error patterns } \\
\hline & \multicolumn{2}{|c|}{ Lax } & \multicolumn{2}{|c|}{ Tense } & \multicolumn{2}{|c|}{ Aspirated } \\
\hline & Tensification & Aspiration & Unfortified & Aspiration & Unfortified & Tensification \\
\hline 2 years & 12.00 & 3.00 & 1.00 & 1.00 & 1.00 & 10.00 \\
\hline 3 years & 3.75 & 0.00 & 0.00 & 0.00 & 0.00 & 7.50 \\
\hline 4 years & 0.00 & 0.00 & 3.10 & 0.00 & 0.00 & 2.04 \\
\hline 5 years & 1.12 & 0.00 & 0.00 & 0.00 & 0.00 & 2.24 \\
\hline 6 years & 0.00 & 0.00 & 0.00 & 0.00 & 0.00 & 0.00 \\
\hline 7 years & 0.00 & 0.00 & 0.00 & 0.00 & 0.00 & 0.00 \\
\hline
\end{tabular}

패턴 종류에 대한 사후검정 결과, 격음의 경음화는 격음의 평음화 보다 유의하게 많이 출현하였다( $p<.05)$.

\section{나이에 적절한 오류패턴 분석}

2 회 이상 보인 음운오류패턴에 대해 각 연령별 출현 비율을 살펴 보았고, 출현 비율이 $10 \%$ 이상일 경우 나이에 적절한 오류패턴으 로 간주하였다. Table 4 에서 볼 수 있듯이, 2세 집단에서 평음의 경 음화와 격음의 경음화가 나이에 적절한 것으로 나타났다.

\section{논의 및 결론}

본 연구에서는 한국어의 방언을 고려하여 대상집단에서 경상도 권 아동들을 제외하였고, 한국어의 말소리 특성을 반영하여 마찰 음이 오조음될 때 기식성이 추가되어도, 어절 내 위치에 상관없이, 이것을 발성오류로 분석하지 않았다. 그 결과, 발성유형에 대한 발 달은 3 세에 거의 완성되어 4 세에 들어서면서 안정화됨을 알 수 있 었다. 세 발성유형 중 격음이 가장 늦게 발달하여 3세까지 평음과 경음보다 정확도가 떨어졌고, 평균적으로는 평음이 가장 먼저 발 달하는 것으로 나타났다. 발성유형 발달과 관련한 선행연구를 살 펴보면, 평음, 경음, 격음 중 평음과 경음이 격음보다 먼저 발달하고 (Kim \& Pae, 2005), 평음보다 경음의 산출 비율이 높다고 보고되었 다(Ahn \& Kim, 2003; Moon \& Ha, 2012). 격음보다 평음과 경음의 정확도가 더 높았다는 점에서 본 연구결과는 선행연구들과 일치한 반면, 경음과 평음의 발달순서 면에서는 다소 차이를 보인다. 이러 한 차이와 관련하여 대부분의 선행연구에서는 자발화 분석을 통 해 결과를 도출한 반면, 본 연구의 경우 단어이름대기 과제를 이용 하여 자료를 수집하였고 단어 내 평음, 경음, 격음 중 평음의 기회수 가 가장 많았다는 점을 상기할 필요가 있다. 이와 관련하여 Park과 $\operatorname{Kim}$ (2015)은 과제가 달라지면서 구체적인 오류 양상에 다소 차이 가 있을 수 있음을 언급하였다. 자음정확도의 경우 단어수준 검사
와 자발화 검사 간 상관관계가 매우 높거나 동일할 수 있는 반면, 오 류패턴은 어느 정도 상이하다는 것이다. 또한, 기존의 UTAP과 현 재 개발중인 UTAP2의 단어수준의 검사 간에도 구체적인 검사항 목이 달라지면서 오류패턴의 양상 또한 달라지는 것이 관찰되었다. 따라서 모든 결과는 주어진 과제에 대한 결과임을 염두에 두어야 할 것이다. 즉, 이와 같은 데이터 수집방법과 자료의 특성이 선행연 구와 다른 결과를 초래한 원인일 수 있다. 말소리를 연속적으로 빠 르게 산출할수록 이후 말소리들에 긴장성이 더해지는 조음운동생 리적 측면을 고려할 때, 적당한 시간간격을 두고 목표단어를 천천 히 산출하게 하는 단어이름대기 과제는 놀이상황의 자발화 과제에 비해 상대적으로 말소리산출에 긴장성이 부가적으로 유발될 기회 가 적다. 또한 일관되게 오조음을 보이는 말소리는 산출기회가 많 을수록 그 오류가 두드러지지만, 비일관적으로 오조음과 정조음을 모두 보이는 말소리에서는 그 반대의 경우가 초래될 수 있다. 본 연 구의 대상자들이 일반아동임을 고려할 때 발성유형에 대해 고착된 오류보다는 가변적인 오류를 보였을 가능성이 있고, 따라서 이 또 한 경음보다 평음의 정확도를 높이는 데에 기여했을 수 있다. 그러 나 이러한 가능성들에 대해서는 추후 자료의 항목수, 수집방법 등 을 달리하여 발성유형별 말소리산출 수행력을 보다 심층적으로 비 교해 보는 후속연구가 필요할 것이다.

세 발성유형 각각에서 오류패턴에 대한 연령별 차이를 살펴본 결 과, 평음과 격음의 오류는 2,3 세에서 가장 빈번하였던 반면, 경음의 오류는 연령별 차이가 관찰되지 않았다. 오류패턴 유형별로는 평음 의 경음화와 격음의 경음화가 빈번하였다. 즉, 어린 연령에서는 평 음과 격음을 경음으로 대치하는 오류를 보일 수 있는데, 이것은 본 연구뿐 아니라 선행연구들에서도 이미 보고된 바 있는 한국어 자 음의 발달적 특성이다(Ahn \& Kim, 2003; Moon \& Ha, 2012). 더불 어 나이에 적절한 오류패턴으로 2 세에서 평음의 경음화와 격음의 경음화로 확인된 세 번째 결과 또한 발성유형에 따른 한국어 자음 발달 특성을 일관되게 보여준 것이다. 반면 경음의 경우, 본 연구에 
서는 경음의 평음화가 경음의 격음화보다 빈번한 것으로 확인되었 다. 앞에서 살펴본 산출정확도의 결과와 종합하여 해석해 보면, 연 령에 상관없이 경음에서도 오류가 발생할 수 있으며 이 경우 평음 으로 대치되는 양상을 보인다. 이와 같은 결과는 유아들에서 평음 과 경음, 경음과 격음 등이 서로 대치되는 현상이 매우 흔하게 발생 한다는 Ahn과 Kim (2003)의 연구를 지지하는 결과이다. 이는 상 대적으로 빨리 발달되는 경음의 경우에도 어린 연령의 아동에게는 발성유형에 대한 음소 경계를 일관되고 명확하게 변별하여 산출하 는 것은 여전히 어려운 과제일 수 있음을 시사한다.

정리하자면, 우리말 평음, 경음, 격음의 발성유형에 따른 차이를 완전히 습득하는 것은 3 세경으로, 아동들은 그리 늦지 않은 시기 에 긴장성과 기식성이라는 변별적 차이를 능숙하게 구분하여 산출 하는 것으로 보인다. 이 중 가장 늦게 발달하는 것은 격음으로, 2 세 에 격음을 경음으로 대치하는 격음의 경음화는 나이에 적절한 오 류패턴이라 할 수 있다. 또한 평음의 경우 평균적으로 가장 먼저 발 달하기는 하였으나 동시에 2 세 아동의 $10 \%$ 이상이 경음으로 대치 하는 평음의 경음화 오류패턴을 보여, 평음의 발달에는 개인차가 있는 것으로 여겨진다.

한국어 세 발성유형의 주된 특성은 음성학적 차이 및 음소적 경 계가 뚜렷하지 않다는 것이다. 그로 인해 세 발성유형은 서로 대치 되어 산출되기 쉬우며, 이와 관련하여 다음과 같이 여러 가지 측면 에서 그 원인이 제기되어 왔다. 첫째, 세 발성유형 간 발성과정의 차 이가 모호하다. 즉, 성문에서 기류조절의 차이가 평음, 경음, 격음 간 차이를 유발하는데(Cho, 2005), 이러한 기류조절은 세 발성유형 간 상대적 차이를 나타낼 뿐, 이에 대한 명확한 경계를 기대하기는 어렵다. 둘째, 세 발성유형 간 조음운동적 차이가 모호하다(Cho, 2005). 평음은 조음 시 조음부의 긴장을 동반하지 않는 반면, 경음 과 격음은 상대적인 긴장성을 동반한다. 24 개월 이전 아동의 경우 미성숙한 구강 움직임으로 인해 평음과 경음, 평음과 격음 간 상대 적 긴장성을 변별하여 산출하는 데에 어려움을 보일 수 있다. 셋째, 세 발성유형 간 음향학적 차이 또한 모호하다. 세 발성유형 중 경음 의 기본주파수가 가장 높은 것으로 알려져 있다(Cho, 2005). 그러 나 후행모음의 음높이가 평음에 비해 경음과 격음이 선행하는 경 우 훨씬 높다고 보고된 바 있는데(Shin, 2000), 이는 경음과 격음의 주파수 경계 또한 명확하지 않음을 시사한다. 이처럼 한국어 발성 유형의 특성은 다른 언어권에 비해 발성, 조음운동적, 음향학적의 여러 측면에서 그 경계의 모호성이 복합적으로 나타난다. 그럼에도 불구하고 일반아동의 경우 발성유형에 대한 이와 같은 복합적이고 모호한 변별을 3 세경에 모두 습득하였다는 점은 매우 놀랍다.

Kuhl, Williams, Lacerda, Stevens와 Lindblom (1992)은 생후
6개월만 되어도 음소적 대립이 가능하다고 보고한 바 있다. 이처럼 조기에 발달되는 영아들의 뛰어난 지각능력과 음성학적 차이에 대 한 민감함을 고려할 때, 말소리발달이 활발하게 이루어지는 초기 연령에는 말소리에 대한 음성학적 특성, 음소적 차원의 경계, 방언 의 영향 등이 아동들의 지각과 산출 수행력에 복합적으로 영향을 미칠 수 있음을 염두에 두어야 할 것이다. 따라서 아동들의 말소리 산출 능력을 평가할 때에는 그동안 간과되었던 지역적 방언의 특성, 발성유형과 같은 한국어의 독특한 특성, 마찰음과 같은 개별 말소 리의 성격, 문맥에 따른 산출 양상의 차이 등을 모두 고려하여야 할 것이다. 이상과 같은 점을 시사하는 본 연구결과는 말소리장애 분 야에 임상적 및 학문적으로 의미 있는 기초자료를 제공할 것으로 기대한다. 그럼에도 불구하고 본 연구는 다음과 같은 제한점을 가 지고 있는데, 단어수준 검사에 한해서만 발성유형별 정확도와 오류 를 살펴보았다는 점이다. 따라서 추후 복잡하고 다양한 문맥에서 더욱 풍부하게 자료를 수집한 후 이에 대한 발성유형별 말소리산출 의차이를 보다 심층적으로 다루는 후속연구가 필요할 것이다.

\section{REFERENCES}

Ahn, M., \& Kim, T. K. (2003). The aquisition process of consonants in early childhood: focusing on segmental correspondences between the child and adult language. Journal of Korean Language Education, 14(2), 169-204.

Burnham, D. K., Earnshaw, L. J., \& Clark, J. E. (1991). Development of categorical identification of native and non-native bilabial stops: infants, children and adults. Journal of Child Language, 18(2), 231-260.

Cho, K. H. (2005). A study on the laryngeal features and the related phonological phenomena in Korean (Doctoral dissertation). Ewha Womans University, Seoul, Korea.

Choi, H. K. (1982). Korea of dialectology. Paju: Taehaksa.

Dodd, B., Holm, A., Hua, Z., \& Crosbie, S. (2003). Phonological development: a normative study of British English-speaking children. Clinical Linguistics \& Phonetics, 17(8), 617-643.

Eimas, P. D., Siqueland, E. R., Jusczyk, P., \& Vigorito, J. (1971). Speech perception in infants. Science, 171(3968), 303-306.

Kim, K. A. (1997). Korean obstruents and laryngeal features. Journal of Korean Linguistics, 30, 35-65.

Kim, M., Kim, S. J., \& Stoel-Gammon, C. (2017). Phonological acquisition of Korean consonants in conversational speech produced by young Korean children. Journal of Child Language, 44(4), 1010-1023.

Kim, M., \& Stoel-Gammon, C. (2009). The acquisition of Korean word-ini- 
tial stops. The Journal of the Acoustical Society of America, 125(6), 39503961.

Kim, M., \& Stoel-Gammon, C. (2011). Phonological development of wordinitial Korean obstruents in young Korean children. Journal of Child Language, 38(2), 316-340.

Kim, M. J. (2006). The phonological error patterns of preschool children in the 'Korean Test of Articulation for Children'. Korean Journal of Communication \& Disorders, 11(2), 17-31.

Kim, M. J., \& Pae, S. Y. (2005). The percentage of consonants correct and the ages of consonantal aquisition for 'Korean-Test of Articulation for Children (K-TAC)'. Speech Sciences, 12(2), 139-141.

Kim, S. J., Cho, H. S., Hwang, Y. M., \& Nam, K. C. (2002). Japanese speakers' perception errors of Korean lenis, aspirated, and fortis consonants. Korean Journal of Communication \& Disorders, 7(1), 166-180.

Kim, Y. T., Hong, G. H., Kim, K. H., Jang, H. S., \& Lee, J. Y. (2009). Receptive \& expressive vocabulary test (REVT). Seoul: Seoul Community Rehabilitation Center

Kim, Y. T., Park, H., Kang, J. K., Kim, J. A., Shin, M. J., Kim, S. J., \& Ha, J. W. (2018). Validity and reliability analyses for the development of Urimal Test of Articulation and Phonology-2. Communication Sciences \& Disorders,
23(4), 959-970.

Kim, Y. T., \& Shin, M. J. (2004). Urimal Test of Articulation and Phonology (UTAP). Seoul: Hakjisa.

Kuhl, P. K., Williams, K. A., Lacerda, F., Stevens, K. N., \& Lindblom, B. (1992). Linguistic experience alters phonetic perception in infants by 6 months of age. Science, 255(5044), 606-608.

Moon, H., \& Ha, S. (2012). Phonological development in toddlers with cleft palate and typically developing toddlers aged 12-24 months. Korean Journal of Communication \& Disorders, 17(1), 118-129.

Park, K., \& Kim, S. J. (2015). A comparison of phonological error patterns in the single word and spontaneous speech of children with speech sound disorders. Phonetics and Speech Sciences, 7(3), 165-173.

Ryu, E. J., \& Ha, J. W. (2019). Development study of speech production by phonation types in Korea children. Proceedings of the 2019 Spring Conference of Korea Society of Speech Science, 147.

Shin, J. Y. (2000). Understand of speech sound. Seoul: Hankookmunhwasa.

Stoel-Gammon, C. (1985). Phonetic inventories, 15-24 months: a longitudinal study. Journal of Speech, Language, and Hearing Research, 28(4), 505512. 
Eun Joo Ryu, et al. • Development of Speech Sound Production by Phonation Types

Appendix 1. Word-level test items of the Urimal Test of Articulation and Phonology-2 (UTAP2)

\begin{tabular}{rlllll}
\hline \multicolumn{5}{c}{ Word-level subtest } & \\
\hline 1 & 나무 & 11 & 해바라기 & 21 & 자동차 \\
2 & 목도리/목또리/ & 12 & 연필 & 22 & 빨간색 \\
3 & 꽃/꼳/ & 13 & 호랑이 & 23 & 짹짹 \\
4 & 김밥/김빱/ & 14 & 라면 & 24 & 그네 \\
5 & 바지 & 15 & 냉장고 & 25 & 기차 \\
6 & 사탕 & 16 & 단추 & 26 & 접시/접씨/ \\
7 & 풍선 & 17 & 곰 & 27 & 로봇/로볻/ \\
8 & 국자/국짜/ & 18 & 가방 & 28 & 싸움 \\
9 & 토끼 & 19 & 똥 & 29 & 짜장면 \\
10 & 코끼리 & 20 & 책상/책쌍/ & 30 & 포크 \\
\hline
\end{tabular}

단어 내에 평음, 경음 또는 격음이 포함되지 않아 본 연구의 분석에서 제외된 UTAP2 항목은 볼드로 처리함. 


\section{국문초록}

\section{한국어 특성을 고려한 2-7세 일반아동의 발성유형별 말소리발달 연구}

류은주 ${ }^{1} \cdot$ 김미진 ${ }^{1} \cdot$ 하지완23.3

${ }^{1}$ 대구대학교 일반대학원 재활과학과 언어치료전공, ${ }^{2}$ 대구대학교 언어치료학과, 일반대학원 재활과학과, ${ }^{3}$ 대구대학교 국제재활과학연구소

배경 및 목적: 본 연구에서는 평음, 경음, 격음의 발성유형에 따른 말소리산출의 발달 양상을 알아보았다. 또한 연령집단 간 각 발성유형 에 대한 오류패턴의 차이를 비교하고, 이 중 나이에 적절한 오류패턴이 무엇인지 파악하였다. 방법: 현재 개발 중인 UTAP2에 포함된 30 개의 단어 중 초성에 장애음을 포함한 총 27개의 단어에 대해, 2-7세 연령별로 평음, 경음, 격음의 정확도를 산출한 후 연령집단 간 차 이를 비교하였다. 이때 한국어의 방언적 특성을 고려하여 경상도권 아동들은 대상에서 제외하였다. 발성유형별로 산출될 수 있는 오류 패턴을 평음의 경음화, 평음의 격음화, 경음의 평음화, 경음의 격음화, 격음의 평음화, 격음의 경음화 6가지로 구분하여, 연령에 따라 유 의한 차이가 있는지 살펴보았다. 그리고 각 오류패턴에 대해 해당 연령대에서의 발생 비율을 산출하여 $10 \%$ 이상의 아동들에서 나타난 오류패턴(나이에 적절한 오류패턴)이 무엇인지 파악하였다. 분석 시 한국어의 마찰음 특성을 고려하여 평음 또는 경음이 오조음될 때 기식성이 추가되는 것은 오류로 분석하지 않았다. 결과: 발성유형에 대한 발달은 3 세에 거의 완성되어 4 세에 들어서면서 안정화되었다. 세 발성유형 중 격음이 가장 늦게 발달하여 3세까지 평음과 경음보다 정확도가 떨어졌고, 평균적으로는 평음이 가장 먼저 발달하는 것 으로 나타났다. 2 세에 평음의 경음화와 격음의 경음화를 보이는 것은 나이에 적절한 오류패턴으로 확인되었다. 논의 및 결론: 본 연구 는 연령에 따른 발성유형별 말소리산출의 정확도와 오류패턴의 발달 양상에 대해 의미 있는 정보를 제공한다. 무엇보다 전국규모의 대 규모 자료에서 지역적 방언의 특성과 한국어 마찰음의 특성을 고려하여 분석을 실시하였다는 점에서 의의가 있다.

핵심어: 평음, 경음, 격음, 한국어 발성유형, 평음의 경음화, 격음의 경음화

본 논문은 2018학년도 대구대학교 학술연구비지원에 의한 논문임.

\section{참고문헌}

김경아(1997). 국어 장애음의 분류와 후두자질. 국어학회, 30, 35-65.

김민정(2006). ‘아동용 조음검사’에 나타난 취학 전 아동의 음운 오류패턴. 언어청각장애연구, 11(2), 17-31.

김민정, 배소영(2005). '아동용 조음검사’를 이용한 연령별 자음정확도와 우리말 자음의 습득연령. Speech Sciences, 12(2), 139-141.

김수진, 조혜숙, 황유미, 남기춘(2002). 일본어 화자의 한국어 평음/기음/경음 지각 오류. 언어청각장애연구, 7(1), 166-180.

김영태, 박희영, 강진경, 김정아, 신문자, 김수진, 하지완(2018). 우리말 조음·음운평가-2(UTAP2) 개발을 위한 타당도 및 신뢰도 분석. Communica-

tion Sciences \& Disorders, 23(4), 959-970.

김영태, 신문자(2004). 우리말 조음·음운평가(UTAP). 서울: 학지사.

김영태, 홍경훈, 김경희, 장혜성, 이주연(2009). 수용·표현어휘력검사(REVT). 서울: 서울장애인종합복지관.

류은주, 하지완(2019). 2-7세 일반아동의 발성유형 별 말소리발달 연구. 2019년도 한국음성학회 봄학술대회 발표논문집, 147.

문희원, 하승희(2012). 12-24개월 구개열 유아와 일반 유아의 음운발달. 언어청각장애연구, 17(1), 118-129.

박가연, 김수진(2015). 아동의 단어와자발화문맥의 음운오류패턴 비교. 말소리와음성과학, 7(3), 165-173.

신지영(2000). 말소리의 이해. 서울: 한국문화사.

안미리, 김태경(2003). 유아의 자음 체계 습득 과정-목표언어와 유아어의 분절음 대응을 중심으로. 한국어교육, 14(2), 169-204

조경하(2005). 국어의 후두 자질과 음운 현상. 이화여자대학교 대학원 박사학위논문.

최학근(1982). 한국방언학. 파주: 태학사. 
Eun Joo Ryu, et al. • Development of Speech Sound Production by Phonation Types

COMMUNICATION SCIENCES\& DISORDERS

\section{ORCID}

류은주(https://orcid.org/0000-0002-8233-6995); 김미진(https://orcid.org/0000-0002-2151-6167); 하지완(https://orcid.org/0000-0002-1191-791X) 